\title{
鉄道車両連結器用緩衝装置の高機能化に関する研究*
}

\author{
早勢 剛*1, 長 南征二*2, 深 澤 香 敏*3
}

\section{Optimum Design of a High Functional Buffer for Railway Vehicles}

\author{
Takeshi HAYASE*4, Seiji CHONAN and Katoshi FUKAZAWA
}

${ }^{* 4}$ Railway Technical Reserch Institute, 2-8-38, Hikari-cho, Kokubunji-shi, Tokyo, 185-8540 Japan

\begin{abstract}
A new hydraulic draft gear, which has a function of controlling the coupler force, is studied in this paper. The purpose of design of the present device "relief buffer" is to lower the coupler force acting between the failed and the relief train set, which is a very important design factor for the structure of Sinkansen electric-car. The relief buffer assuming the idealized displacement-load characteristics is introduced into the coupling device of the failed train set consisting of 8 light weight new prototype Sinkansen electric ${ }^{-}$cars and the effect of the relief buffer on the system dynamics is investigated, from which the required specifications are determined on the buffer. Farther, an excitation test is conducted on the prototype buffer composed of a hydraulic cylinder, a servo valve and a feedback controller. The results obtained show that the basic performance of the buffer is satisfactory for the control of coupler force.
\end{abstract}

Key Words: Railway, Dynamics of Machinery, Damping, Coupler Force, Draft gear, Sinkansen

\section{1. 緒言}

列車の加減速や連結時の打ち当てによる衝撃を吸収 するため, 鉄道車両の連結装置には緩衝器が備えられ ている. 構造が簡単で安価なゴム緩衝器が一般的で, 積載荷重が非常に大きい一部の貨車や急こう配区間に 専用される電気機関車には油圧やシリコン流体の粘性 抵抗を利用したものも実用化されている。これらは変 位とともに剛性が漸増する非線形ばね特性や, ピスト ン速度に依存する変位一荷重特性を有する。 近年，鉄道車両に対するアクティブ制御技術の導入 が進められ，例えば車体支持装置には高速走行時の乗 心地改善を目的としたシステムが実用化されてい る(1)。一方, 連結装置については, 乗心地の向上を目 的としたゴム緩衝器の改良や衝突を想定した衝撃吸収 要素の検討(2)などが進められている。しかし, 車両の 強度や列車編成の運動特性などについて, 積極的な制 御技術の応用により緩衝器特性の最適化を図るものは

* 原稿受付 2000 年 3 月 27 日.

*1 正員, 鉄道総合技術研究所 (画 185-8540 東京都国分寺市光町 2-8-38)

*2 正員, 東北大学大学院 ( $\$ 980-0845$ 仙台市荒巻字青葉).

*3 鉄道総合技術研究所.

E-mail : hayase@rtri.or.jp
少ない.

新幹線電車の強度設計においては，本線上で故障し た場合にこれを救援する際の連結器作用力(以下では 「自連力」と呼ぶ)が重要である(3).したがって, 緩衝 器特性の最適化によりそのピーク值を低減できれば, 救援列車の運転取扱いに対する規制の緩和や軽量, 省 力化に不可欠な車体構体の合理的強度設計に資するこ とができる。そこで本研究では，もっぱら救援時に使 用される固定編成先頭部の連結装置に着目し, 緩衝器 特性の最適化による自連力低減を検討している. 従来 に比較して構体端部の強度が大幅に抑えられた新幹線 車両を想定し, 先頭部緩衝器の大容量, 高機能化につ いて要求仕様や効果を数值解析により定量的に把握す る.また, 油圧緩衝装置を試作して定置試験による基 本性能の確認を行う.

\section{2. 新幹線の救援問題}

$2 \cdot 1$ 併結救援時の自連力 故障や破損により本 線上で走行不能となった新幹線電車に健全な編成を連 結して救援する場合には, 各部の強度や列車座屈に対 する安全性確保の観点から自連力が問題とされ, 東海 道新幹線では開業後に車両各部の強化や緩衝器性能の 改善が図られた(3). 自連力が特に増大するのは, 故障 


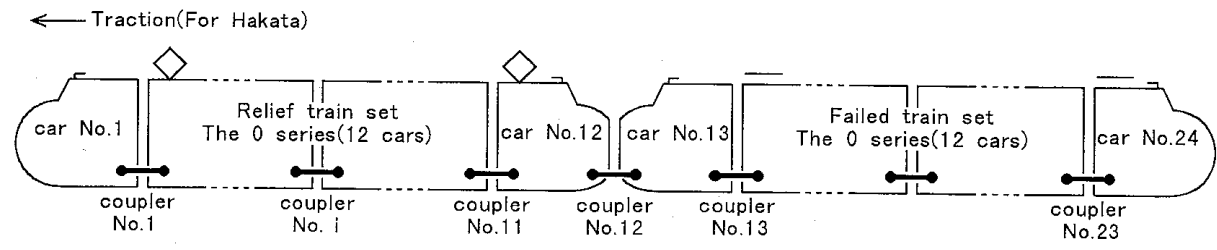

(a) The condition of releif test on Tokaido-Shinkansen

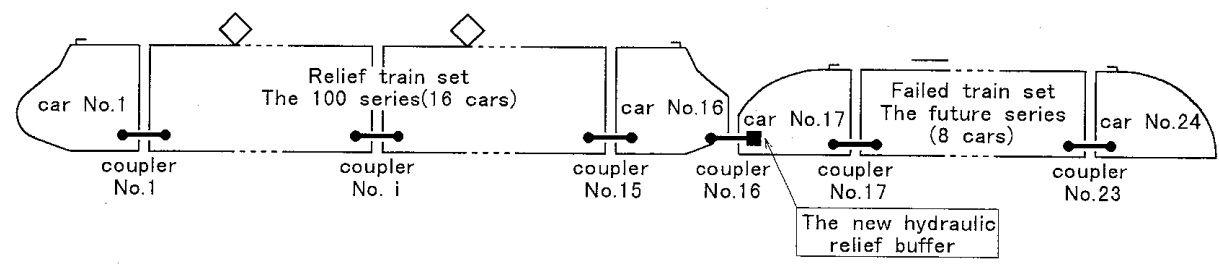

(b) The condition under which peformance of draft gears are studied

Fig. 1 The relief train conditions studying in this paper

編成のブレーキが作用せず救援編成が低速 $(20 \mathrm{~km} / \mathrm{h}$ 以下)から強いブレーキを扱う場合で，これは制輪子 摩擦係数の速度依存性などに起因する，例えば，図 1 （a）に示寸編成で過去に実施された救援試験では，牽 引運転で救援編成 (1〜 12 号車)のみに常用最大ブレー キが作用した際, 併結部 (連結器番号 $i=12$ ) の圧縮自 連力最大值がー $500 \mathrm{kN}$ (本研究では压縮力を負とす る）を超えた。

これと同一条件の数值解析結果を図 2 に示す.レ心゙ ル線で起動加速後 $v_{0}=10 \mathrm{~km} / \mathrm{h}$ で力行を off し, 同時 に常用最大ブレーキ(ブレーキハンドル操作角度 $\phi_{H}=$ $110^{\circ}$ )を扱うものとした。図 2 (a) は各連結部の自連 力解析波形 $\left(F_{c i}, i=1 \sim 23\right)$ で, ブレーキ操作時を $t=0$ としている. 加速性能の上限に近い率引力で引張状態 $\left(F_{c i}>0\right)$ にある各連結部は, ブレーキ操作から約 1 秒 で併結部から編成両端に向かい順次圧縮状態になる。 ブレーキシリンダ圧力の過渡上昇特性などに依存して 救援編成の制動力が定常值となるのに約 2.5 秒かかる ことなどから，各部の圧縮自連力がピーク值 $\left(F_{c i \max }\right)$ に達するのはブレーキ操作から 3〜3.5 秒後である. 各連結部の $F_{c i \text { max }}$ を図 $2(\mathrm{~b})$ に示す。救援試験にお ける $F_{c 12,14 \max }$ の実測值 $(\triangle)$ を併せてプロットした。 圧縮自連力のピーク值は併結部が最も大きく, 編成両 端に向かってほほ対称に減少している。

このように併結救援列車で問題となるのは，救援側 の制動力が静定する前後に併結部などで生じる過渡的 な自連力のピーク值である。これは，減速度が均衡す る過程で両編成間に生じる相対運動エネルギーを各緩 衝器が一時的に吸収して発生するもので, ピーク值の 低減には緩衝器のエネルギー吸収容量搪大が有効とさ れる。

本研究で用いる数值解析手法は，列車編成に関する

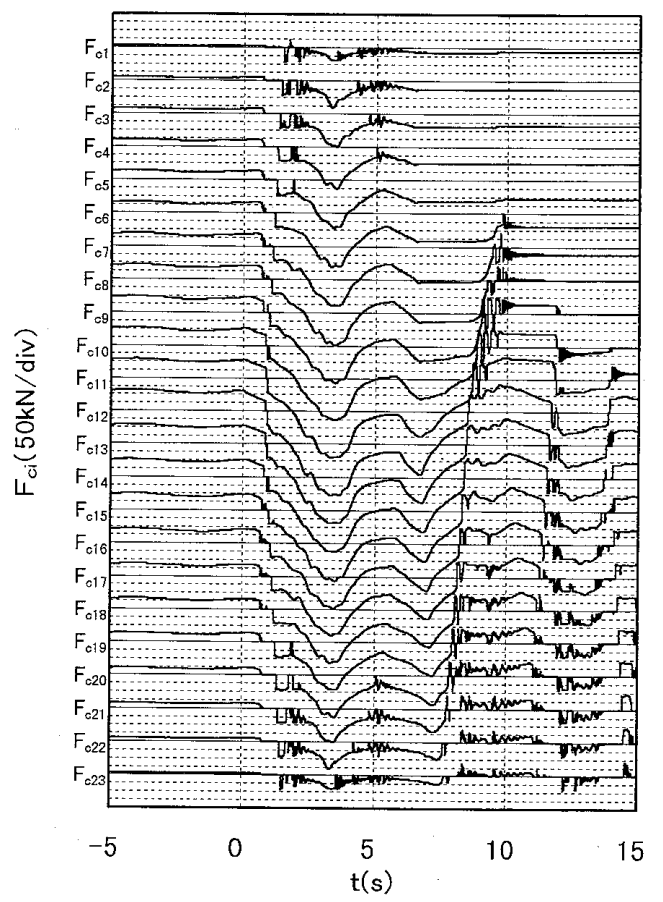

(a) Response of Coupler Forces

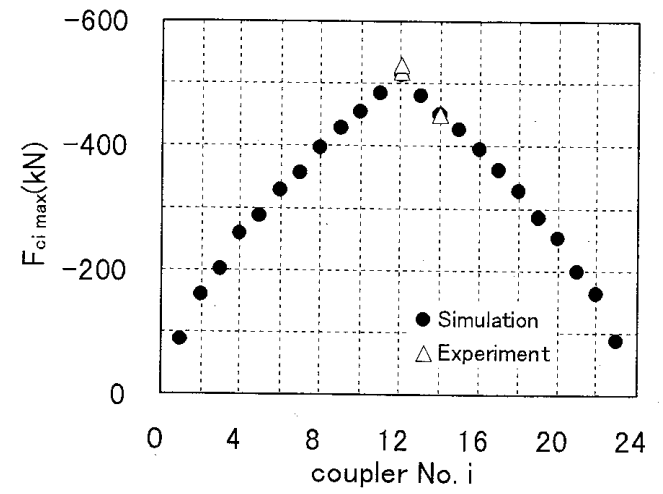

(b) $F_{c \max }$ at each coupling position

Fig. 2 Numerical analysis of coupler Force. Level, Traction, $v_{0}=10 \mathrm{~km} / \mathrm{h}, \psi_{h}=110 \mathrm{deg}$ 


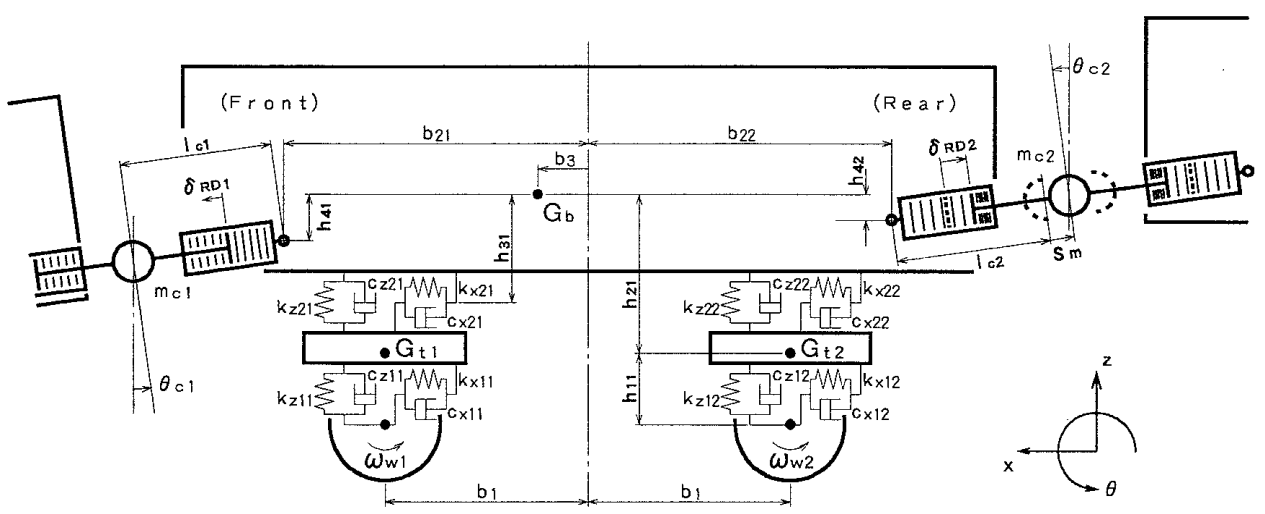

Fig. 3 Geometory of car model

多自由度非線形運動方程式の時間応答解を求めるもの である，図 3 に示す解析モデルは車体，台車のばね間， ばね下質量および連結器に相当する集中質量 $m_{c i}$ で 構成され，おのおのについて以下の状態変数を導入す る.

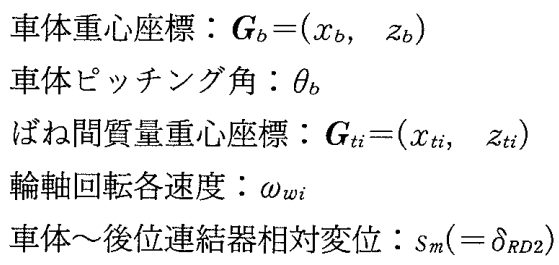
後位を表す添字である。これらを合せた状態べクトル $\boldsymbol{q}$ に関する運動方程式は

$$
\boldsymbol{M} \cdot \ddot{\boldsymbol{q}}=\boldsymbol{F}^{R D}+\boldsymbol{F}^{K C}+\boldsymbol{F}^{W}
$$

で与えられ，慣性項と緩衝器力 $\boldsymbol{F}^{R D}$, ばね減衰力 $\boldsymbol{F}^{K C}$ およびその他の外力項 $\boldsymbol{F}^{W}$ から成る， $\boldsymbol{F}^{W}$ はばね下質 量に付加される駆動および制動モーメントなどであ る. $x, z, \theta$ 方向の車体運動自由度に対する緩衝器力 項は

$$
\begin{aligned}
& F_{b, x}^{R D}=F_{R D 1} \cdot \cos \theta_{c 1}-F_{R D 2} \cdot \cos \theta_{c 2} \\
& F_{b, z}^{R D}=-F_{R D 1} \cdot \sin \theta_{c 1}+F_{R D 2} \cdot \sin \theta_{c 2} \cdots \cdots \\
& M_{b, \theta}^{R D}= \\
& \quad-\left\{h_{41} \cdot \cos \left(\theta_{c 1}-\theta_{b}\right)-\left(b_{21}-b_{3}\right) \cdot \sin \right. \\
& \left.\quad \times\left(\theta_{c 1}-\theta_{b}\right)\right\} \cdot F_{R D 1} \\
& \quad+\left\{h_{42} \cdot \cos \left(\theta_{c 2}-\theta_{b}\right)+\left(b_{22}+b_{3}\right) \cdot \sin \right. \\
& \left.\quad \times\left(\theta_{c 2}-\theta_{b}\right)\right\} \cdot F_{R D 2}
\end{aligned}
$$

で与えられる。ここに

$F_{R D 1,2}$ : 前, 後位緩衝器発生力 $(+$ : 引張)

$\theta_{c 1,2}$ : 前, 後位連結装置ピッチング角

$h_{41,2}$ : 前, 後位連結器回転中心～車体重心高さ

$b_{21,2}$ : 前, 後位連結器回転中心 台車間中心距離

$b_{3}$ : 車体重心前後偏寄量 $(+$ ：前位側 $)$

自連力は緩衝器の変位および変形速度 $\delta_{R D i}, \quad \dot{\delta}_{R D i}$ から
逐次計算されるその発生力 $F_{R D 1,2}$ として得られる。例

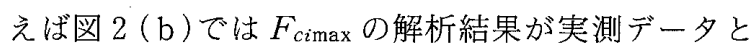
ほぼ一致しているが，このほかにも自連力応答波形の 比較などにより解析精度を確認している(4).

$2 \cdot 2$ 併結救援時の自連力低減整備新幹線の延 伸や輸送需要への柔軟な対応を背景に, $12 〜 16$ 両が一 般的であった新幹線電車の編成形態は近年多様化する 傾向にある。比較的短編成の新形式車両も投入され， 例えば長野新幹線の E 2 系や山陽新幹線の 700 系は 8 両編成で，これらの空車総質量は在来線の 201 系通勤 電車の 10 両編成 $(6 \mathrm{M} 4 \mathrm{~T}, 376 \mathrm{t})$ より小さい.このよ うな運用形態の車両について高速化や省力化に必要な 車体構成の軽量化を今後検討する場合には，自連力に 関する強度設計を在来線電車なみに合理化できる可能 性がある，ただし，この場合には既存編成による併結 救援時の自連力低減が課題となる.

そこで本研究では, 救援時の自連力ピーク值を構体 強度などに関する任意の目標值に抑制する緩衝装置を 提案する. 発生頻度の極めて低い救援運転に備え，全 車に特殊な緩衝器を備えることは不合理であること， 乗心地を重視する通常運用時とは要求特性が基本的に 異なることなどから, 救援に専用される固定編成先頭 部の連結装置に着目し，現行車両では編成中と同一の ものが使用されている緩衝器の大容量, 高機能化を検 討する(以下ではこれを「救援用緩衝器」と呼ぶ)。

\section{3. 救援用緩衝器に関する数値解析}

救援用緩衝器の仕様やその実現により得られる効果 を定量的に把握するため，目標とする特性を仮定して 先に述べた手法を応用した自連力の数值解析を行った 結果について述べる.

\section{$3 \cdot 1$ 車両条件}

$3 \cdot 1 \cdot 1$ 車両諸元最近の新幹線高速試験車両で は，自連力に対する構体強度を確認する車端圧縮試験 
荷重(現行 $980 \mathrm{kN}^{(5)}$ ) を $490 \mathrm{kN}$ に抑えて車体の軽量 化を図った例がある(6). 本研究では, これと同等の質 量諸元, 構体強度を有する仮想の 8 両編成が救援され るケースを検討した。図 1 ( b ) に救援列車の編成を示 す.力行および制動機能のない故障編成各車(17～24 号車)の空車質量は $36 \mathrm{t}$ で，より厳しい条件を考慮し て車体重心に現行営業車の定員乗車に相当する質量 6 $\mathrm{t}$ を付加する. 救援編成は既存車両中で比較的重い 100 系 (1〜16 号車, 編成質量 $860 \mathrm{t}$ ) とした. 垂直座屈 を防止するため，実際の併結救援取扱いと同様に各車 の空気ばねはパンク状態とし, 車体上下支持剛性(図 3 の $\left.k_{z 21,2}\right)$ は $20 \sim 30 \mathrm{MN} / \mathrm{m}$ である.

$3 \cdot 1 \cdot 2$ 緩衝器条件解析では救援編成各車に適 用する緩衝器について, 以下の 3 ケースを比較検討し た.

・条件 A すべて RD 011 A ゴム緩衝器

・条件 B すべて RD 19 ゴム緩衝器

- 条件 C 17 号車前位(故障編成先頭部)に救援用 緩衝器, 他は RD 011 A ゴム緩衝器

$\mathrm{A}$ は現行条件, B は各部の緩衝器容量を現行の約 2 倍 とするケース，Cは強度設計の合理化を図った仮想編 成の先頭部に救援用緩衝器を適用するケースである.

$3 \cdot 1 \cdot 2 \cdot 1$ ゴム緩衝器 RD $011 \mathrm{~A}$ は新幹線電車, RD 19 は大形貨車に用いられるゴム緩衝器で，おのお のの変位一荷重特性曲線(緩衝ゴムの使用荷重曲線)を 図 4 に示す. RD $011 \mathrm{~A}$ は初圧 $\left(\delta_{R D}=0\right.$ の荷重)がな く, 圧縮, 引張荷重で作用する緩衝ゴムが異なるため 非対称性があり，最大荷重は引張 $784 \mathrm{kN}$, 圧縮 980 $\mathrm{kN}$ である。初圧 $78 \mathrm{kN}$ の RD 19 はストロークが長 く，同一最大荷重 $(980 \mathrm{kN})$ に対する吸収エネルギー は RD 011 A (圧縮)の約 2 倍である.

$3 \cdot 1 \cdot 2 \cdot 2$ 救援用緩衝器本研究で提案する救援 用緩衝器の構成を図 5 に, 解析で用いた目標特性を図 6 に示す。これはシリンダ，ピストン復元ばね，サー ボバルブなどで構成される油圧装置で，フィードバッ

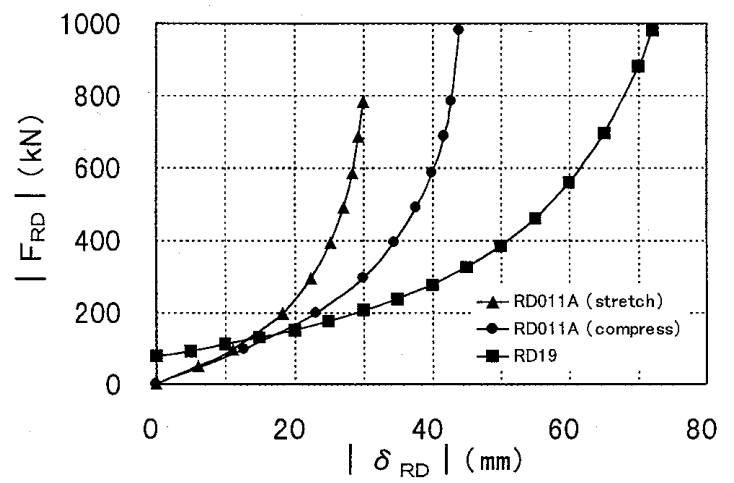

Fig. 4 Characteristics of rubber draft gears
ク制御により自連力 (抵抗力 $F_{p}$ ) を任意の一定値に維 持しながらピストンを変位させる機能を有する，連結 器に引張, 圧縮いずれの力が作用してもシリンダ内の 油を制御弁を介してタンクに排出する方向にピストン 変位 $\delta_{p}$ が生じる． $F_{p}$ は油压による $F_{h y d}$ とばね力 $F_{k}$ の和である.タンクは $\delta_{p}$ に伴うピストンロッド分の 容積変化を吸収する。

図 6 の目標特性に沿って救援用緩衝器の動作を概説 する． $F_{p}$ が制御目標 $F_{r e f}$ に満たない時は，制御弁を 閉鎖して作動油の圧縮性による高剛性のばね特性を示 す. $F_{r e f}$ に達すると制御弁を開き， $\delta_{p}, \dot{\delta}_{p}$ に依らず $F_{p}$ を $F_{r e f}$ に維持しながら $\delta_{p}$ が増加して衝撃エネル ギーを吸収，消散する． $\delta_{p} \geqq \delta_{e}$ ではピストンがストッ パに接触し， $F_{p}>F_{r e f}$ となれば制御弁は解放される。 戻り行程では油がバイパスを介してシリンダ内へ流入 するため， $\delta_{p} \geqq \delta_{e}$ では復元ばね $k_{r}$ とストッパばね $k_{e}$ が, $\delta_{p}<\delta_{e}$ では $k_{r}$ のみが作用する。

$F_{r e f}$ を強度や列車座屈に関する自連力目安值とす れば，これらに対する安全性を確保しながら緩衝容量 をほほ最大にできる，本研究ではこれを構体強度に関 する自連力限度值 $(490 \mathrm{kN})$ として故障編成の先頭部 に用い，併結部の自連力低減効果や他部位への影響な どを検討した。解析に用いた救援用緩衝器の諸元を以 下に示す。

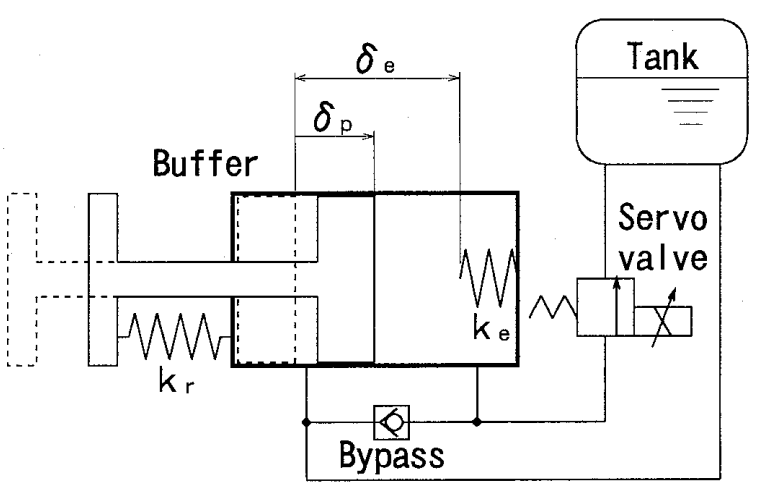

Fig. 5 Composition of the relief buffer

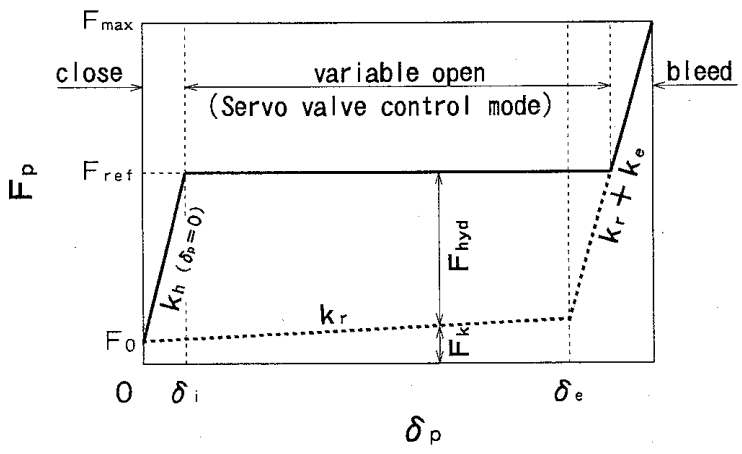

Fig. 6 Idealized characteristics of the relief buffer 
有効ストローク $\delta_{e}=300 \mathrm{~mm}$

シリンダ内径 $\quad d=140 \mathrm{~mm}$

復元ばね初圧 $\quad F_{0}=9.8 \mathrm{kN}$

制御目標荷重 $\quad F_{r e f}=490 \mathrm{kN}$

最大荷重 $\quad F_{\max }=980 \mathrm{kN}$

復元ばね剛性 $\quad k_{r}=88.2 \mathrm{kN} / \mathrm{m}$

ストッパばね風性 $k_{e}=49.0 \mathrm{MN} / \mathrm{m}$

$\delta_{e}$ は連結部の車体間距離 (通常 $500 \mathrm{~mm}$ ) や機器配置 などに制約されるが, 本研究では大容量化のため RD $011 \mathrm{~A}$ の取り付け長程度まで拡大した。実用化に 際しては緩衝器支持部の構体構造変更や連結装置の長 尺化が必要である， $d$ は大物車の油緩衝器で実績のあ る值， $k_{r}$ は $d$ および $\delta_{e}$ を考慮して取付幅が一般的な 伴板寸法 $(300 \mathrm{~mm})$ に収まるように設計したコイルば ねの剛性である。

数值解析では作動油に一定の体積弾性係数 $\beta$ を仮 定し(7)，制御弁閉鎖時の剛性 $k_{h}$ を式 (5)で計算する. $\beta=1.37 \times 10^{9} \mathrm{~N} / \mathrm{m}^{2}$ とすれば, $\delta_{p}=0$ において $k_{h}=70$ $\mathrm{MN} / \mathrm{m}$, 図60 $\delta_{i}$ は約 $7 \mathrm{~mm}$ である.

$$
k_{h}=\frac{\beta}{\delta_{p}} \cdot\left[\frac{\pi \cdot d^{2}}{4}\right]^{2}
$$

目標特性に沿って $\delta_{p}$ が 0 から $\delta_{e}$ まで変位する際吸 収されるエネルギ一は，復元ばねによるものを含めて $145 \mathrm{kN} \cdot \mathrm{m}$ で，その $96 \%$ は油圧回路で消散される。 こ れは RD 011 A の 12 倍, RD 19 の 6 倍に相当する(い ずれも最大荷重に対する值で比較)。

$3 \cdot 2$ 運転条件本研究では救援編成 (100系)が 故障編成を牽引して走行中に, 非常ブレーキを扱うケ 一スを検討している。運転取扱いについては以下に示 す 2 種類とした。

・条件 I レベル線上で惰行状態から非常ブレーキを 扱う場合で，このとき各連結部は遊間の中立位置にあ るものとする.

・条件II $20 \%$ の上りこう配上で起動加速中に, 力行 off と同時に非常ブレーキを扱う場合で，このとき各 連結部は救援編成の毫引力による引張状態にある. I では制動時の編成状態を同一とし，ブレーキ初速度 $v_{0}$ や緩衝器条件 $(\mathrm{A} \sim \mathrm{C})$ が自連力に及ぼす影響の把握 を目的とする. 各部が定常的な引張状態から圧縮へ移 行して前後衝動が生じるIIでは, 比較的厳しい運転取 扱いで発生する自連力の上限や救援用緩衝器に対する 要求仕様を推定する。したがって, 起動率引力は力行 性能の上限に近い値 $(100$ 系, 約 $400 \mathrm{kN})$ とし，これを 連続して付加することから軌道条件は東海道新幹線の 最急こう配としている(8).

緩衝器条件 (A，B，C)および運転条件 ( I , II)が異
なる $3 \times 2=6$ ケースについて，ブレ一キ初速度 $v_{0}$ (5〜20 km/h, $1 \mathrm{~km} / \mathrm{h}$ 刻み)をパラメータとして応答 解析を行った。

\section{$3 \cdot 3$ 解析結果}

$\mathbf{3} \cdot \mathbf{3} \cdot 1$ 自連力最大值 牽引運転で制動力が救援 編成のみに作用するため, 図 2 のケースと同様各部の 自連力最大值 $F_{c i \text { max }}$ はブレーキ操作直後に生じる圧 縮のピーク值である. 運転条件 II, $v_{0}=10 \mathrm{~km} / \mathrm{h}$ の場 合について, 緩衝器条件 $\mathrm{A} \sim \mathrm{C} て ゙ F_{c i \max }$ を比較した結 果を図 7 に示す。構体強度に関する自連力の限度は救 援側 $(i=1 \sim 15)$ が $-980 \mathrm{kN}$, 併結部を含む故障側 $(i$ =16〜23)がー490 kN である.

全車を現行の RD $011 \mathrm{~A}$ とした条件 A では故障側 の $i=16 〜 18$ で $F_{c i \max }$ が限度を超過する. また, 緩衝 容量に余裕が少ないため $i=9 \sim 15 て ゙ F_{c i \max }$ が併結部 より増加する。これに対し全車を RD 19 とした条件 $\mathrm{B}$ では, 救援編成中の $F_{c i \max }$ が併結部から離れる程単 調に減少してゴム緩衝器の容量拡大効果が認められ る。しかし， $i=16 \sim 18$ では $F_{c i \max }$ が限度を超過す る.一方, 故障編成の先頭部に救援用緩衝器を用いた 条件 C では併結部が限度值に，故障編成中の各部はこ れ以下に抑えられる。救援側でも条件 $\mathrm{A} に$ 比較して 最大 $200 \mathrm{kN}$ 程度 $F_{c i \max }$ が低減される。

図 7 に示したケースを含め故障編成の各部を通じて はいずれも併結部の自連力 $\left(F_{c 16 \max }\right)$ が最も大きく，こ れとブレーキ初速度 $v_{0}$ の関係を図 8 に示す.（a）は ブレーキ操作時の編成状態を同一とした運転条件 I の 場合で, 緩衝器条件 A，Bにはばらつきの小さい緩や かな速度依存性が認められる。これはブレーキキライ ニング摩擦係数の速度依存性に起因するもので, $v_{0}$ が 低いほど制動初期の減速度が高く $F_{c 16 \max }$ は大きい。 ただし， $v_{0}$ が過小になると自連力が極大值に達する前

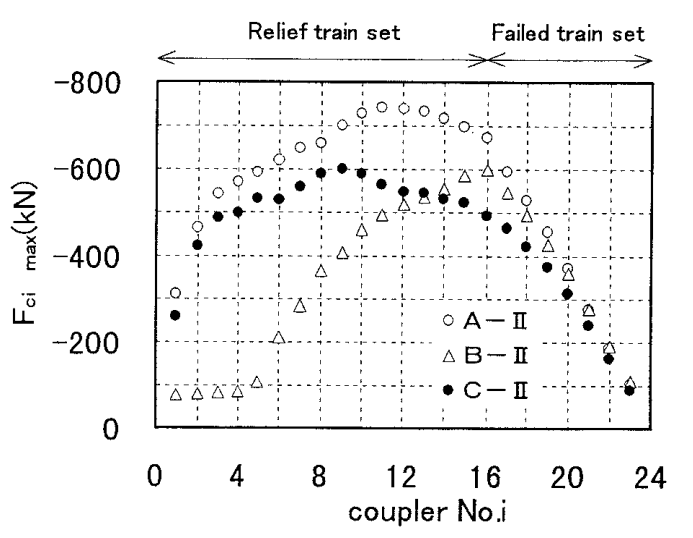

Fig. $7 \quad F_{c \max }$ at each coupling position. Operating condition case II $+20 \%$, Traction, $v_{0}=10 \mathrm{~km} / \mathrm{h}$, Emargency break 


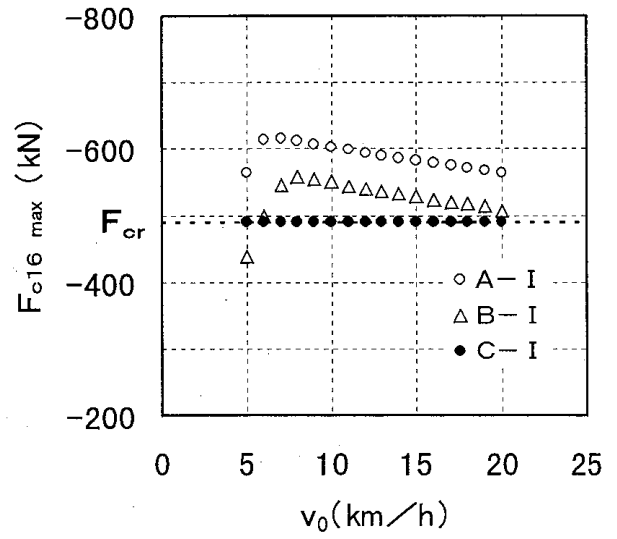

(a) Operating condition case I Level, Traction, Emargency break

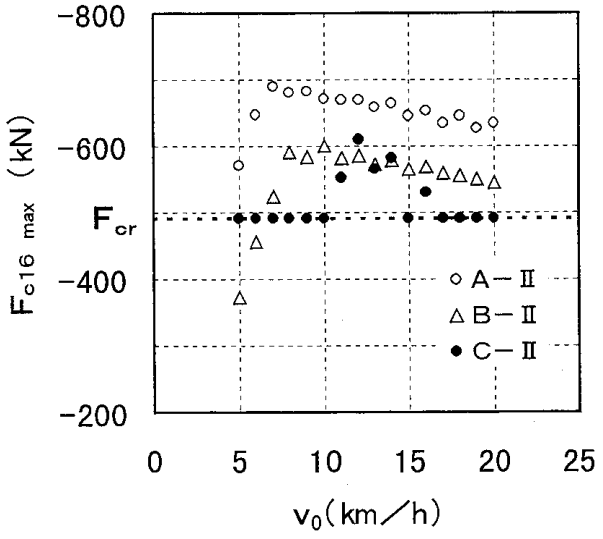

(b) Operating condition case II $+20 \%$, Traction, Emargency break

Fig. $8 \quad F_{c 16 \max }$ dependence of $v_{0}$

に編成が停止するため， $v_{0}<10 \mathrm{~km} / \mathrm{h}$ にピークがあり， $v_{0} \leqq 20 \mathrm{~km} / \mathrm{h}$ に押ける $F_{c 16 \max }$ の変化は $100 \mathrm{kN}$ 末満 である。条件 A，B-Iのデータがほとんど限度值 $\left(F_{c r}=-490 \mathrm{kN}\right)$ を越えるのに対し, 救援用緩衝器を 用いた C-I のデー夕は $v_{0}$ に依らず $F_{c r}$ に抑えられて いる.

図 8（b）はこう配起動後速度が $v_{0}$ となるまで救援 編成が力行する条件IIの場合で，A，B-IIにはI と同 様の速度依存性が認められる。 作の夕イミングが異なって編成状態に差が生じるた め,データが若干ばらつく、緩衝器条件および $v_{0}$ 同 一で $F_{c 16 \max }$ を比較すると打打む放 I より IIが大きく 最大值は-688 kN(A-II, $\left.v_{0}=7 \mathrm{~km} / \mathrm{h}\right)$ である. 救援 用緩衝器ではこれが約 $200 \mathrm{kN}$ 低減されて $F_{c r}$ に抑え られる $\left(\mathrm{C}-\mathrm{II}, v_{0}=7 \mathrm{~km} / \mathrm{h}\right) . v_{0}=11 \sim 14,16 \mathrm{~km} / \mathrm{h}$ で は C-IIでも $F_{c 16 \max }$ が $F_{c r}$ を超過する。これは， $v_{0} の$ 上昇により制動時間とともに压縮自連力の作用時間が 増加し， $\delta_{p}$ が伸びてピストンがストッパに接触する ためである. $v_{0} \geqq 17 \mathrm{~km} / \mathrm{h}$ ではライニング摩擦係数の 低下でストッパの接触が回避される。

$3 \cdot 3 \cdot 2$ 救援用緩衝器の所要性能救援用緩衝器 のピストン変位最大值 $\delta_{p \max }$ とブレーキ初速度 $v_{0}$ の 関係を図 9 に亦す. C-I では $10 \mathrm{~km} / \mathrm{h}$ 付近にピーク が認められ， $\delta_{e}(=300 \mathrm{~mm})$ に対して余裕がある。一 方，C-IIではストッパが接触する 11〜 $16 \mathrm{~km} / \mathrm{h}$ にお いて $\delta_{p \max }$ が頭打ちとなり，自連力が増加する極端な 運転条件で有効ストローク $\delta_{e}$ が不足する可能性が考 えられる。

ストッパ接触により $F_{c 16 \max }$ がー $600 \mathrm{kN}$ を超えた ケース(C-II， $\left.v_{0}=12 \mathrm{~km} / \mathrm{h}\right)$ の解析波形例を図 10 に 示す. 1,24 号車の速度 $v_{1,24}$, ピストン変位 $\delta_{p}$, 併結

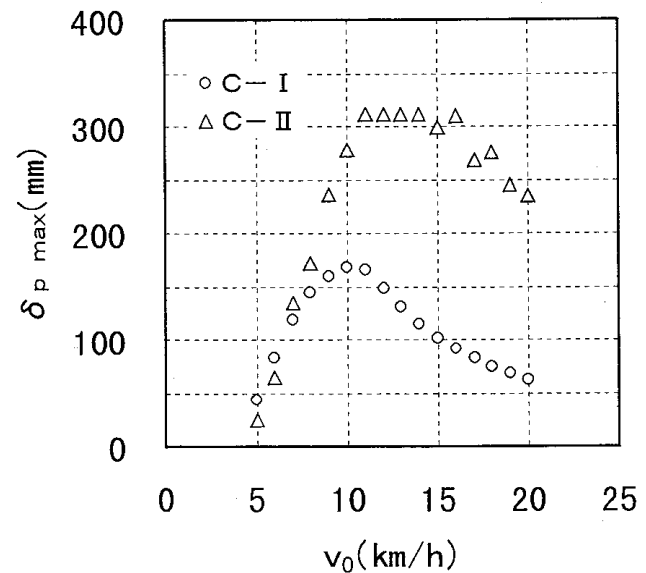

Fig. $9 \delta_{p \max }$ dependence of $v_{0}$

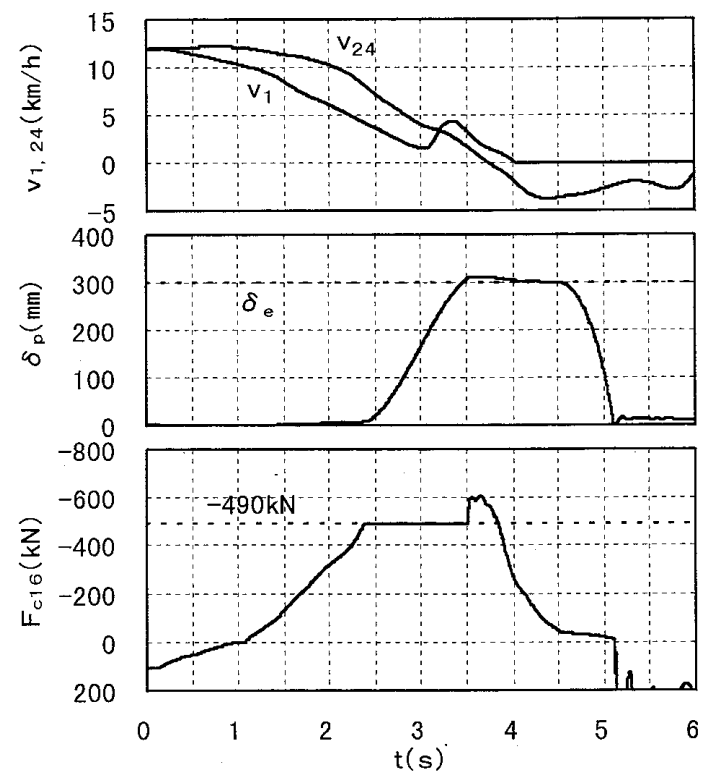

Fig. 10 Response of the relief buffer. $+20 \%$, Traction, $v_{0}=10 \mathrm{~km} / \mathrm{h}$, Emargency break 
部の自連力 $F_{c 16} お$ おおのの時間応答波形で, ブレー キ操作時を $t=0$ とした. ブレーキ操作から約 2.3 秒 で $F_{c 16}$ がー490 kN に達すると,これを維持しながら $\delta_{p}$ が増加する． $\delta_{p}$ は約 3.5 秒で $\delta_{e}$ を超え，ストッパ が接触して $F_{c 16}$ がステップ状に立ち上がる，この夕 イミングは併結部から伝ぱした衝撃により $v_{1}$ が一時 的に増加した後であり, 各部の圧縮状態はすでにピー クを過ぎていることから所要ストロークは $300 \mathrm{~mm}$ を大幅には超えないと推定される. 仮に $\delta_{e}=400 \mathrm{~mm}$ とすればストッパ接触はなくなり， $\delta_{p \max }$ の最大值は $361 \mathrm{~mm}\left(v_{0}=14 \mathrm{~km} / \mathrm{h}\right)$ となることなどから, 比較的 厳しい運転条件を考慮しても所要ストロークは 400 $\mathrm{mm}$ 程度と考えられる.

図 10 で $F_{c 16}$ が一定值に維持される約 1.2 秒間のピ ストン速度 $\dot{\delta}_{p}$ は $300 \mathrm{~mm} / \mathrm{s}$ 程度である. 条件IIの各

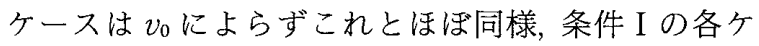
一スはいずれも $200 \mathrm{~mm} / \mathrm{s}$ 程度であることから, 油圧 制御系には $300 \mathrm{~mm} / \mathrm{s}$ 程度のピストン速度を許容する 流量性能および応答特性が必要と考えられる。

救援編成が故障編成を後押しする推進運転の場合に は,ブレーキ操作直後に発生する引張自連力ピーク值 の抑制が問題となる．構体強度に関する自連力限度を $+490 \mathrm{kN}$ とすれば, 救援用緩衝器の所要性能や動作 は牽引時とほぼ同一と考えられる。ただし，圧縮と引 張でRD 011 A の特定が異なるため (図 4 参照), 自連 力絶対值やピストン変位が増加する可能性がある。そ

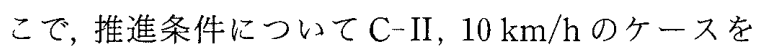
解析した結果, 牽引条件に比べ $\delta_{p \max }$ は約 $15 \mathrm{~mm}$ 増 加したが $F_{c 16 \max }$ は $+490 \mathrm{kN}$ に抑えられ, 故障編成の 自連力絶対值は牽引とほとんど変わらなかった。

\section{4. 試作緩衝器による定置特性試験}

$4 \cdot 1$ 試験概要 $3 \cdot 1 \cdot 2$ 項で述べた特殊な油圧緩 衝装置によって実際に得られる特性や制御ロジックの 検討を行うため, 試作器を製作して定置特性試験を実 施した，有効ストローク $\delta_{e}$ を縮小した場合に在来線 電車へ装架できる構造とするため, 復元ばねの初压や 剛性を低く抑えた点を除き油圧シリンダ部はおおむね 数值シミュレーションの諸元を満たす。制御目標荷重 やピストン速度の要求仕樣を考慮し, 油圧系には 34.3 $\mathrm{MPa}, 0.3 \mathrm{~m}^{3} / \mathrm{min}$ まで制御可能なサーボバルブ [カ ヤバ工業(株)製, IPVS-E 30] を採用している。試作 器ではタンクを含むバルブュニットと油圧シリンダを 別置の構成とした。

本研究では図 11 に示す簡易な出力フィードバック 制御系を構成し, ピストンに強制変位 $\delta_{p}$ (三角および

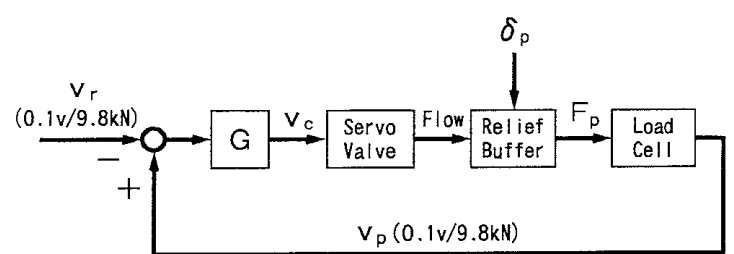

Fig. 11 Control system for bench test

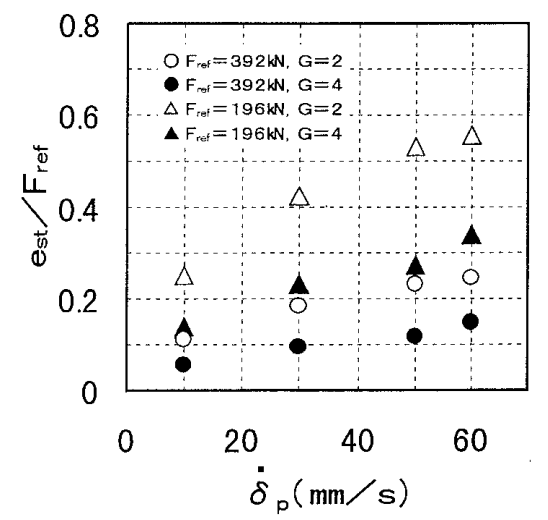

Fig. 12 Effect of the control system. Triangular wave, $a_{0}=50 \mathrm{~mm}, f=0.05 \sim 0.3 \mathrm{~Hz}$

正弦波)を与えて抵抗力 $F_{p}$ などを測定した. 復元ば 䘞性 $k_{r}$ に依存する戻り行程の追従性から，家を $100 \mathrm{~mm} / \mathrm{s}$ 以下に抑えるため, 強制変位は土50 mm, $0.05 \sim 0.3 \mathrm{~Hz}$ としている. 制御目標荷重 $F_{r e f}$ は指令 電圧 $v_{r}$ で設定し， $F_{p}$ による出力電圧 $v_{p}$ との偏差に 一定のゲイン $G$ を乗じてバルブの開度指令電圧 $v_{c}$ を 決定する. $v_{c}=1.0 \sim 8.2 \mathrm{~V}$ に対して閉鎖から全開ま で開度 (ポペット変位 0 ～12 mm)がリニアに調整され

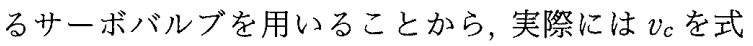
(6)で求める.

$$
v_{c}=\left[\begin{array}{c}
\left(v_{p}-v_{r}\right) \cdot G+1.0 \\
: v_{p}>v_{r} \\
0 \quad v_{p} \leqq v_{r}
\end{array}\right.
$$

$4 \cdot 2$ 定置試験結果 $\quad \dot{\delta}_{p}$ 一定の三角波強制変位 では, 圧縮行程においてピストン抵抗力が一定值 $F_{p s t}$ に収束することが確認された，収束後の残留偏差 $e_{s t}$ $\left(=F_{p s t}-F_{r e f}\right)$ と $\dot{\delta}_{p}$ の関係を図 12 に示す. $G$ およ び $F_{r e f}$ の異なる 4 ケースごとに $e_{s t} / F_{r e f}$ をプロット した. $e_{s t}$ は $\dot{\delta}_{p}$ とともに増加する傾向を示し,フィ ードバックゲインを大きくすればある程度改善され る。 $F_{\text {ref }}$ が小さいほどその効果は明確であるが, $G>$ 4 とすると安定性が損なわれることから, 偏差の積分 值に比例する制御動作などによる $e_{s t}$ の抑制が必要と 考えられる(9).

正弦波強制変位に対する対応波形例を図 13 に示す。 ピストンをあらかじめ圧縮した状態を原点 $\left(\delta_{p}=0\right)$ と する 3 周期の $\delta_{p}-F_{p}$ 軌跡である. $f=0.1 \mathrm{~Hz}$ の (a) 


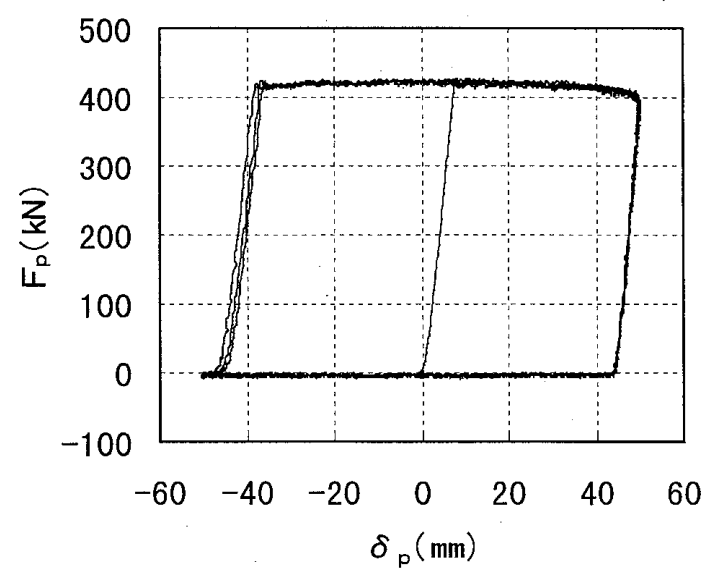

(a) Sine wave, $F_{\text {ref }}=392 \mathrm{kN}, G=4 a_{0}=50 \mathrm{~mm}, f=0.1 \mathrm{~Hz}$, $\dot{\delta}_{p \max }=31.4 \mathrm{~mm} / \mathrm{s}$

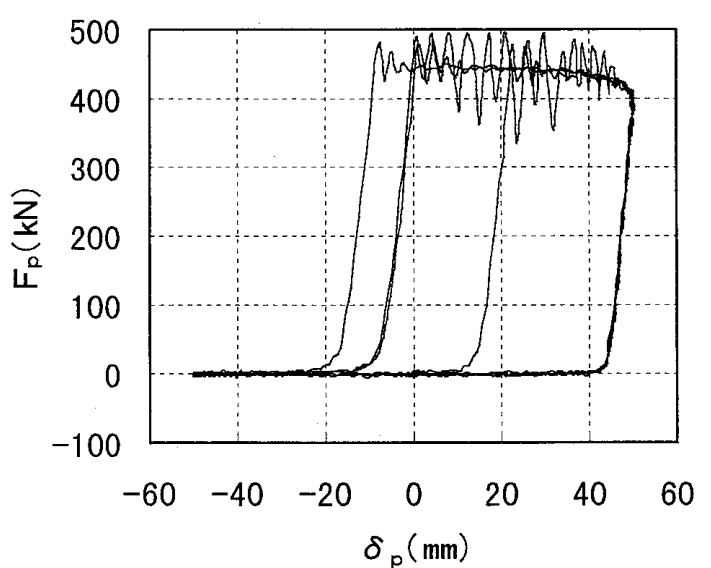

(b) Sine wave, $F_{\text {ref }}=392 \mathrm{kN}, G=4 \quad a_{0}=50 \mathrm{~mm}, f=0.3 \mathrm{~Hz}$, $\dot{\delta}_{p_{\max }}=94.2 \mathrm{~mm} / \mathrm{s}$

Fig. $13 \delta-F$ response of the relief buffer

では $F_{p}$ が静定するまでにピストンが約 $13 \mathrm{~mm}$ 変位 する(以下ではこれを「無効変位」と呼ぶ). $\dot{\delta}_{p}$ がピ ークとなる原点付近を中心に残留偏差がやや増加する が, $\delta_{p} \leqq 31.4 \mathrm{~mm} / \mathrm{s}$ の強制変位に対してほほ一定のピ ストン抵抗が得られ，戻り行程ではこれが速やかに減 少している.一方, $f=0.3 \mathrm{~Hz}$ の (b)では無効変位が 40 $50 \mathrm{~mm}$ に拡大し， $\dot{\delta}_{p} \leqq 94.2 \mathrm{~mm} / \mathrm{s}$ の強制変位に 対して $F_{p}$ に発散が見られる. $G=2$ として発散を抑 えると, 原点近傍の残留偏差が $100 \mathrm{kN}$ を超え, 偏差 の微分值に比例する制御動作などによる㷌還制御系の 安定化が必要と考光られる(9).

ピストン速度の増加に伴う無効変位の拡大は, 三角 波強制変位の条件でも見られ，戻り行程におけるシリ ンダ内への作動油吸い込み不足が一因と考えられる。 したがって, バイパス回路(図 5 参照)の容量拡大が必 要である.

\section{5. 結論}

新幹線電車の強度設計において重要な救援時の連結 器作用力 (自連力) 低減を目的とし, 編成先頭部の連結 器緩衝装置に着目して大容量, 高機能化を検討した。 多自由度非線形モデルによる救援列車の自連力解析 と, 試作緩衝装置の定置特性試験により得られた結果 を以下にまとめる。本研究では，強度設計の合理化に より車体構体の強度に対する自連力限度が $490 \mathrm{kN}$ に 抑えられた仮想の編成(空車質量 $36 \mathrm{t}, 8$ 両)を, 在来 編成 (100 系, 空車質量 48～56 t, 16 両) が救援する場 合を検討した。

・自連力を限度值に抑えながらピストンが変位して衝 撃を吸収する救援用油圧緩衝装置の目標特性を仮想編
成先頭部に適用すると, 現行のゴム緩衝器に比較し最 大で $200 \mathrm{kN}$ 自連力が低減される.

・本研究の救援用緩衝装置を編成先頭部に用いれば, 全車に大形貨車用のゴム緩衝器を装架する以上に自連 力を低減できる可能性がある.

・自連力が増加する極端な運転条件を考慮すれば, 救 援用緩衝装置のストロークは $400 \mathrm{~mm}$, ピストン速度 は $300 \mathrm{~mm} / \mathrm{s}$ で設計する必要がある。

・簡易な出力フィードバック制卸による試作緩衝装置 の定置試験では, $100 \mathrm{~mm} / \mathrm{s}$ 以下の強制変位に対して ピストン抵抗力が一定值に収束することが確認でき た.

今後は PID 制御器の適用や油圧回路の改善によっ て所要性能の実現を図り，現車装架条件で性能を確認 するとともに信頼性の向上などを検討していく.

最後に, 試作緩衝装置の設計製作および定置試験に ご尽力を賜った，カヤバ工業(株)相模工場制振装置部 露木保男室長はじめ関係各位に深く感謝する。

\section{文献}

（1）牧寛司・ほか 3 名，カヤバ技報，第 19 号 (1999)，43-47.

（2）大西登喜夫・活加 4 名, 機構, 920-98 (1992), 86-89.

（3）鉄道技術研究所, 高速鉄道の研究 (1967)，197-198, 研友 社.

（4）早勢剛・ ほ加 1 名, 機論, 66-646, C (2000), 1943-1951.

（5）日本規格協会, 日本工業規格「鉄道車両構体の荷重試験 方法」(JIS E 7105).

（6）石津一正・䚾加 4 名, 車両技術, 207 号 (1995)，3-19，(社) 日本鉄道車軜工業会.

（7）石田弘明・淰か 4 名, 機構, 920-55 (1992), 586-591

（8）新幹線研究会, 詳解新幹線 (1975. 12.)，219-221, (社)日本 鉄道運転協会.

（9）長屋幸助・ほか 3 名，メカトロニクスと運動制御入門 (1996), 108-110, 養賢堂. 